УДК 61(07.07)(436)

\title{
ПІДГОТОВКА ДОКТОРІВ НАУК 3 МЕДСЕСТРИНСТВА В УНІВЕРСИТЕТАХ АВСТРІї
}

Г. Б. Паласюк

ДВНЗ “Тернопільський держсавний медичний університет імені І. Я. Горбачевського МОЗ Украйни”

\section{TRAINING OF DOCTORS OF SCIENCE ON NURSING IN THE UNIVERSITIES OF AUSTRIA}

\author{
H. B. Palasiuk \\ SHEI "Ternopil State Medical University by I. Ya. Horbachevsky of MPH of Ukraine”
}

\begin{abstract}
У статті проаналізовано програми докторантури з медсестринства в університетах Австрії. Обгрунтовано важливе значення вивчення зарубіжного досвіду організації навчального процесу для підвищення рівня підготовки медичних сестер в Україні.
\end{abstract}

The article analyzes the programs of doctoral studies on nursing in the universities of Austria. There was substantiated the significance of studying the foreign experience of educational process organization for increasing of training level of nurses in Ukraine.

Вступ. У вищій медичній школі України реалізується євроінтеграційна програма підготовки медичних працівників у відповідності до міжнародних стандартів, метою якої є достойне входження до європейського освітнього і наукового простору. Значна увага приділяється реформуванню медсестринської освіти. Впроваджується ступенева підготовка медичних сестер, розпочато підготовку медичних сестер $з$ вищою освітою, що дозволить удосконалити підготовку ліцензованих медичних сестер і підвищити якість надання медсестринських послуг.

Основна частина. У пошуках шляхів удосконалення підготовки медичних сестер в Україні цінним $\epsilon$ вивчення зарубіжного досвіду організації навчального процесу. Значний науковий інтерес викликає підготовка медичного персоналу по догляду за хворими 3 вищою освітою - докторів наук в Австрії.

Зважаючи на це, метою статті є вивчення досвіду організації навчального процесу при підготовці докторів наук з медсестринства в Австрії.

Впровадження вищої медсестринської освіти і подальший розвиток сестринської справи як науки розглядається австрійськими науковцями як пріоритетний напрямок реформування системи підготовки сестринського персоналу Австріі. Тут доцільно зауважити, що реформування вищої, в тому числі медичної освіти, розпочалось в Австрії у 2002 році із прийняттям Федеральним парламентом країни Закону про університети (Universitatsgesetz 2002) [1]. Цей процес різко активізувався зі зміною організаційної структури університетів: у 2004 році від трьох класичних універси(ㄷ. Г. Б. Паласюк тетів - Відня, Іраца й Інсбрука від’єднались медичні факультети, які утворили три незалежні медичні університети зі статусом повної автономії [2].

Наукові дослідження з проблем догляду за хворими виокремились в окрему наукову спеціальність “Сестринствознавство” (Pflegewissenschaft). Основоположним принципом сестринської справи проголошено їі орієнтованість більшою мірою на людину, ніж на хворобу. Предметом наукових досліджень в догляді за хворими стало, з одної сторони, вивчення впливу захворювань і фізичних вад на життя людини, а $з$ другої - наукове обгрунтування найбільш доцільних форм медсестринської діяльності і медсестринських втручань у процесі догляду за хворими і такими, що потребують опіки [3].

У 2005 році при факультеті суспільних наук Віденського університету розпочав свою діяльність Інститут сестринствознавства, що стало ще одним кроком вперед у формуванні наукового потенціалу науки з догляду за хворими. У цьому ж році тут відкрито докторантуру із сестринствознавства, розпочали свої наукові дослідження перші докторанти.

Обов' язковою умовою для вступу в докторантуру при Інституті сестринствознавства є звання магістpa, яке підтверджує придатність майбутнього докторанта до проведення наукових досліджень i свідчить про наявність у нього необхідних дослідницьких навиків, без яких неможливе продовження навчання в докторантурі.

Зауважимо, що магістратура - вищий ступінь медсестринської освіти після бакалаврату. Ступінь ба- 
калавра в Австрії не вважається науковим. Бакалаврат розширює можливості наступного працевлаштування у практичній охороні здоров'я і $є$ необхідною умовою для здобуття наукового ступеня магістра $\mathrm{i}$ доктора медсестринства.

Умовою вступу до магістратури з медсестринства $\epsilon$ успішне закінчення бакалаврату з медсестринства або диплом дипломованої медсестри і університетські студії бакалаврського рівня з медсестринства. Можна також вступити до магістратури після закінчення бакалаврату з іншої спеціальності. У цьому випадку вимагається складання вступних іспитів.

Існують різні магістерські програми з медсестринства: медсестринствознавство, педагогіка в медсестринстві, менеджмент в медсестринстві, геріатрична і геронтологічна експертиза тощо [4].

Програма магістратури 3 медсестринства [5] має не тільки академічну, а й професійну спрямованість, тому, крім фундаментальних, включає також практично-орієнтовані дослідження, спрямовані на наукову організацію медсестринського процесу. Кожен університет має повну автономію щодо змісту навчальних програм $з$ магістратури.

Найвищим в освітній градації Австрії є звання доктора наук. Метою програми докторантури з сестринствознавства Віденського університету [6] $є$ дослідницька робота. Шляхом написання дисертації докторанти проводять дослідження 3 теорії і практики сестринської діяльності.

Навчання в докторантурі Віденського медичного університету триває 3 роки і складається 3 двох етапів. На першому етапі після виконання всіх необхідних вимог докторант самостійно або з допомогою наукового консультанта складає розгорнутий проект дисертаційного дослідження. На цьому етапі докторант може відвідувати заняття, на яких він отримує необхідну допомогу у плануванні дисертаційного дослідження.

Матеріали планування докторської дисертації вивчає спеціально створена комісія, яка робить висновок щодо відповідності методичного і наукового рівня дисертаційного дослідження вимогам до дисертацій на здобуття наукового ступеня доктора наук. Розглянуті комісією матеріали затверджуються на засіданні ради факультету, яке проводиться на початку і наприкінці кожного семестру. Позитивна оцінка матеріалів планування докторської дисертації дозволяє докторанту перейти до наступного етапу докторантури.

Другий етап розпочинається укладенням угоди між докторантом і його консультантом, у якій кожна сторона зобов'язується виконувати певні зобов'язання. Наступний крок-визначення змісту 30 кредит-годин, які повинен засвоїти докторант за час навчання в докторантурі. Заняття, які докторант відвідував до укладання угоди, вважаються підготовчими i, як правило, не зараховуються. 20 кредитів зараховується докторантові за засвоєння обов' язкових дисциплін, вивчення щонайменше 15 з яких завершується складанням іспиту. Участь у конференціях, майстер-класах, тренінгах для формування ключових компетенцій, практика та інші види діяльності зараховуються в тому випадку, коли вони мають відношення до дисертації.

Згідно з Програмою докторантури Віденського університету [6], розробленою Програмною комісією і затвердженою на засіданні Сенату університету від 23 квітня 2009 року, всі заняття повинні проводитись на високому методичному, професійному і науковому рівні. За прослуховування лекцій докторантам зараховується 3 кредит-години. Лекції виголошуються у формі доповіді з мультимедійним супроводом і присвячені тематиці наукових досліджень. Досить поширені композиційні лекції, які об’єднують декілька незалежних, але змістово поєднаних доповідей декількох науковців. Наприкінці семестру докторанти складають усний або письмовий екзамен.

Семінари для докторантів проводяться у формі дискусій, обміну думками з проблем наукового дослідження і оцінюються максимально 7 кредит-годинами.

Науково-дослідний колоквіум проводиться у вигляді семінару, у якому беруть участь докторант і його консультант. Такий вид занять оцінюється 5 кредитгодинами.

Після завершення навчання, написання дисертаційної роботи і позитивноїії оцінки науковим керівником, відбувається захист дисертації, після якого дисертантові відповідно до $\S 51$ Закону про університети [1] присвоюється вчене звання доктора філософії.

У 2005 році запроваджені програми з магістратури i докторантури із сестринствознавства в Грацькому медичному університеті.

Як і в інших університетах, для вступу в докторантуру з сестринствознавства Грацького медичного університету вимагається успішне закінчення магістратури. Програма докторантури реалізується у міжнародному вимірі - частина занять проводиться в Шаріте-Університеті медицини (Берлін, Німеччина) і Університеті Мааштріхт (Нідерланди).

У 2011 році розроблена нова Програма докторантури із сестринствознавства Грацького медичного університету [7], яка набула чинності 1 жовтня 2011 року. У ній зазначено, що метою навчання в докторантурі з медсестринства $є$ формування здатності через проведення власних наукових досліджень і впро- 
вадження їх результатів у практику сприяти науковій організації медсестринської професійної діяльності, формуючи таким чином науковий потенціал для догляду за хворими.

Докторанти самостійно планують і проводять наукове дослідження з актуальних проблем медсестринства, здобувають й аналізують нові наукові факти, розвивають здатність критично оцінювати результати своїх дослідно-експериментальних пошуків і робити теоретичні узагальнення. Здобута в докторантурі кваліфікація дозволяє докторантові у майбутньому працювати як в університеті, так і в практичній сфері професійної діяльності в міжнародному контексті.

Навчання в докторантурі 3 сестринствознавсва Грацького медичного університету триває 8 семестрів і передбачає засвоєння певних дисциплін, складання комплексного іспиту, написання і захист докторської дисертації. Заняття відбуваються у форматі блоків почергово в Австрії, Німеччині або Нідерландах. Щонайменше половина навчальних занять i консультацій проводяться в Грацькому медичному університеті. Заняття, консультації та іспити проводяться англійською мовою.

За час навчання докторанти повинні відвідувати заняття $з$ дисциплін, передбачених Програмою докторантури з медсестринства.

На заняттях 3 “Основ наукових досліджень і поглиблення наукових досліджень 1 і 2" докторанти здійснюють планування дисертаційної роботи, проводять наукові дослідження, здійснюють статистич- ну обробку, аналіз і інтерпретацію даних, розробляють різні моделі імплементації наукових теорій в практичну діяльність, обговорюють основні положення наукового дослідження.

На дисертаційних семінарах в так званих тематичних групах проводиться презентація результатів наукового дослідження, обговорюються проблеми, методика і хід дисертаційних досліджень, висловлюються критичні зауваження і відбувається активна аргументована дискусія щодо окремих положень наукової роботи.

Окремі семінарські заняття присвячені науковопубліцистичній діяльності докторантів. На цих семінарах докторанти пропонують для обговорення частини своїх дисертаційних робіт і статті для публікацій в міжнародних наукових журналах, а також висловлюють свої думки і дискутують щодо наукових публікацій з актуальних проблем сестринської діяльності.

Докторанти повинні брати активну участь у конференціях, в тому числі і щорічних Свропейських докторських конференціях з проблем догляду за хворими. Участь у конференції означає виголошення доповіді з візуальною презентацією.

У таблиці 1 подано види занять, їх тривалість і місце проведення у розрізі окремих семестрів [7].

Докторантура з сестринствознавства передбачає обов'язкове написання дисертації. Докторська дисертація повинна бути самостійним оригінальним науковим дослідженням актуальних проблем з догляду за хворими. Дисертація є підтвердженням здатності докторанта самостійно розробити і запропонувати нові підходи

Таблиця 1. Куррікулюм докторантури з медсестринства Грацького медичного університету

\begin{tabular}{|l|c|l|}
\hline \multicolumn{1}{|c|}{ Вид заняття } & Кількість годин & \multicolumn{1}{|c|}{ Місце проведення заняття } \\
\hline 1 семестр & 2 & $\begin{array}{l}\text { Шаріте, Мааштріхт, Грацький медичний } \\
\text { університет }\end{array}$ \\
\hline $\begin{array}{l}\text { Основи наукових досліджень і поглиблення } \\
\text { наукових досліджень у медсестринстві 1 }\end{array}$ & 1 & $\begin{array}{l}\text { Шаріте, Мааштріхт, Грацький медичний } \\
\text { університет }\end{array}$ \\
\hline Вступ до дисертаційного семінару & 0,5 & Грацький медичний університет \\
\hline Презентація теми дисертації, консультація & 1 & $\begin{array}{l}\text { Шаріте, Мааштріхт, } \\
\text { Грацький медичний університет }\end{array}$ \\
\hline 2 семестр & 1 & $\begin{array}{l}\text { Шаріте, Мааштріхт, } \\
\text { Грацький медичний університет }\end{array}$ \\
\hline $\begin{array}{l}\text { псглови наукових досліджень і } \\
\text { у медсестринстві 2 }\end{array}$ & $\begin{array}{l}\text { Шаріте, Мааштріхт, } \\
\text { Грацький медичний університет }\end{array}$ \\
\hline $\begin{array}{l}\text { Вступ до публіцистичної діяльності } \\
\text { Дисертаційний семінар }\end{array}$ & 0,5 & Грацький медичний університет \\
\hline Консультація і проміжний звіт & 2 & $\begin{array}{l}\text { Шаріте, Мааштріхт, } \\
\text { Грацький медичний університет }\end{array}$ \\
\hline з семестр & $\begin{array}{l}\text { Шаріте, Мааштріхт, } \\
\text { Грацький медичний університет }\end{array}$ \\
\hline $\begin{array}{l}\text { Публіцистична діяльність } \\
\text { Грацький медичний університет }\end{array}$ \\
\hline $\begin{array}{l}\text { Дисертаційний семінар } \\
\text { Консультація і проміжний звіт }\end{array}$ & 0,5 & 1 \\
\hline
\end{tabular}


Продовження табл. 1

\begin{tabular}{|c|c|c|}
\hline Вид заняття & Кількість годин & Місце проведення заняття \\
\hline \multicolumn{3}{|l|}{4 семестр } \\
\hline Публіцистична діяльність & 2 & $\begin{array}{l}\text { Шаріте, Мааштріхт, } \\
\text { Грацький медичний університет }\end{array}$ \\
\hline Дисертаційний семінар & 1 & $\begin{array}{l}\text { Шаріте, Мааштріхт, } \\
\text { Грацький медичний університет }\end{array}$ \\
\hline Консультація і проміжний звіт & 0,5 & Грацький медичний університет \\
\hline \multicolumn{3}{|l|}{5 семестр } \\
\hline Публіцистична діяльність & 2 & $\begin{array}{l}\text { Шаріте, Мааштріхт, } \\
\text { Грацький медичний університет }\end{array}$ \\
\hline Дисертаційний семінар & 1 & $\begin{array}{l}\text { Шаріте, Мааштріхт, } \\
\text { Грацький медичний університет }\end{array}$ \\
\hline Консультація і проміжний звіт & 0,5 & Грацький медичний університет \\
\hline \multicolumn{3}{|l|}{6 семестр } \\
\hline Публіцистична діяльність & 2 & $\begin{array}{l}\text { Шаріте, Мааштріхт, } \\
\text { Грацький медичний університет }\end{array}$ \\
\hline Дисертаційний семінар & 1 & $\begin{array}{l}\text { Шаріте, Мааштріхт, } \\
\text { Грацький медичний університет }\end{array}$ \\
\hline Консультація і проміжний звіт & 0,5 & Грацький медичний університет \\
\hline \multicolumn{3}{|l|}{ 7-8 семестр } \\
\hline Консультація & & Грацький медичний університет \\
\hline \multicolumn{3}{|l|}{ 3-8 семестр } \\
\hline Презентації: наукові (міжнародні) конференції & & \\
\hline
\end{tabular}

до вирішення актуальних професійних проблем і його здатності до науково-дослідницької діяльності взагалі.

Науково-дослідні роботи виконуються в руслі наукової роботи інституту, в якому навчається докторант. Основні положення дисертації повинні бути висвітлені у щонайменше чотирьох одноосібних публікаціях у провідних наукових журналах. Дисертація складається зі вступу, опису методики і отриманих результатів проведеного дослідження, основної частини, у якій викладені основні положення дисертаційного дослідження, і висновків. Текст дисертації повинен бути написаний англійською мовою, висновки - англійською і німецькою мовами.

При написанні дисертації докторантові допомагають два консультанти, а в разі необхідності запрошується і третій консультант, який, як правило, є фахівцем з теми дисертації докторанта.

Програма докторантури закінчується складанням комплексного випускного усного іспиту (Abschlussrigorosum). До реєстрації для складання цього іспиту докторант допускається після складення іспитів з усіх предметів і отримання позитивної рецензії на свою дисертацію. Рецензування роботи проводиться щонайменше двома рецензентами - габілітованими науковцями або відомими фахівцями з теми дисертації.

Комплексний іспит включає захист дисертації і екзамен зі спеціальності, за якою захищається дисертація. Після захисту дисертації випускники докторантури отримують вчене звання Doktor der
Pflegewissenschaft (доктор наук 3 догляду за хворими), скорочено Dr. rer. cur.

Приватний університет охорони здоров'я, медичної інформатики і техніки (Private Universitat fur Gesundheitswissenschaften, Medizinische Informatik und Technik Tirol, UMIT ) $є$ третім серед університетів, у яких у 2005 році відкрито програму докторантури 3 догляду за хворими. Заснований у 2004 році на базі медичного факультету університету Інсбрука, у 2005 році Приватний університет охорони здоров' я, медичної інформатики і техніки (далі - UMIT) перебазувався у Тірол і був акредитований як самостійний вищий приватний навчальний заклад.

До вступу в докторантуру UMIT допускаються як дипломовані медсестри і магістри після успішного закінчення університету або професійної вищої школи, так і випускники університетів інших спеціальностей - юристи, економісти, педагоги. Про можливість останніх навчатися в докторантурі у кожному конкретному випадку вирішує комісія, у повноваження якої входить призначення для претендента додаткового екзамену за програмою магістратури $з$ догляду за хворими.

Необхідною умовою вступу в докторантуру $є$ також обрання і погодження з консультантом напрямку і теми наукового дослідження. Навчання в докторантурі UMIT триває 6 семестрів (табл. 2 ), хоча можлива і скорочена програма - 4 семестри. 
Таблиця 2. Куррікулюм докторантури з медсестринства UMIT

\begin{tabular}{|c|c|c|}
\hline Семестр & Тема & ECTS \\
\hline 1 & $\begin{array}{l}\text { - Вступ в наукову роботу } \\
\text { - Інформаційний пошук } \\
\text { - Вибір напрямку і тематики дослідження } \\
\text { - Визначення об’єму дослідження } \\
\text { - Аналіз наукових публікацій для визначення стану розробки проблеми }\end{array}$ & 3 \\
\hline 2 & $\begin{array}{l}\text { - Представлення огляду наукових публікацій з теми дисертації } \\
\text { - Уточнення теми дисертації } \\
\text { - Формулювання мети і завдань наукового дослідження } \\
\text { - Визначення методів наукового дослідження } \\
\text { - Складання розгорнутого плану дослідження }\end{array}$ & 3 \\
\hline 3 & $\begin{array}{l}\text { - Представлення розгорнутого плану дисертації } \\
\text { - Проведення наукового дослідження }\end{array}$ & 3 \\
\hline 4 & $\begin{array}{l}\text { - Монографія: завершення написання теоретичної частини } \\
\text { - Кумулятивна дисертація: публікація статей і підготовка чорнового варіанта } \\
\text { дисертації }\end{array}$ & 3 \\
\hline 5 & $\begin{array}{l}\text { - Подання дисертації рецензування } \\
\text { - Робота над зауваженнями }\end{array}$ & 3 \\
\hline 6 & $\begin{array}{l}\text { - Завершення роботи над дисертацією } \\
\text { - Складання комплексного іспиту, захист дисертації }\end{array}$ & $\begin{array}{l}3 \\
6\end{array}$ \\
\hline Всього & & 24 \\
\hline
\end{tabular}

Програма 3 докторантури має вузькі спеціалізації - медсестринська експертиза, медсестринський менеджмент, педагогіка і геронтологія.

Дисертаційна роботаповинна бути незалежною дослідницькою роботою, яка вносить значний вклад у подальший розвиток медсестринської науки. До захисту наукове дослідження може подаватись у формі кумулятивної дисертаційноїроботи. Програма докторантури вважається виконаною, якщо докторант виконав 120 кредит-годин, захистив дисертацію, склав усний кваліфікаційний іспит з однієї $з$ профілюючих дисциплін і два додаткові іспити. Після захисту дисертації докторантові присуджується вчене звання доктора наук з медсестринства.

Висновок. Реформування медсестринської освіти в Австрії дозволило розробити систему ступеневої підготовки фахівця з медсестринства, спрямованої на

\section{Лiтература}

1. Bundesgesetz uber die Organisation der Universitaten und ihre Studien(Univesitatgesetz 2002-UG). StF : BGBI. 1 N.120/ 2002(Nr: GPXXIRV 1134AB 1224).-Wien:Bundesministerium fur Wissenschaft und Forschung, 2002. - 111 S.

2. Die Reform des Medizinstudiums an der Medizinischen Fakultat/G. Reibnegger, J. Haas, H. Neges, J. Smolle//Zeitschrift fur medizinische Ausbildung. - Witten, 2008. - 3(3). - S. $48-61$.

3. Brandenburg H. Pflegewissenschaft. Lehr- und Arbeitsbuch zur Einfuhrung in wissenschaftliches Denken in der Pflege / H. Brandenburg, S. Dorschner. - Bern : Verlag Hans Huber, 2006. - 264 S. цілісний розвиток особистості майбутнього спеціаліста, створення таких умов навчання, які дозволяють студентам самостійно отримувати необхідну інформацію, аналізувати проблемні питання, знаходити шляхи їх вирішення, формують здатність застосовувати знання для вирішення професійних завдань. Важливим чинником оптимізації підготовки сестринського персоналу в Австрії є академізація медсестринської освіти - впровадження в австрійських університетах програм магістратури i, особливо, докторантури, що дозволило підняти рівень підготовки медичних сестер до світових стандартів. Вивчення і творче використання досвіду підготовки австрійських медичних сестер з одночасним збереженням цінних напрацювань вітчизняної освіти дозволить нам успішно влитись до європейського освітнього простору.

4. Kriegl M. Akademisierung der Pflege in Osterreich / Marianne Kriegl // Bildung und Professionalisierung in der Pflege. - Wien, 2009. - S. 7-21.

5. Curriculum fur das Masterstudium Pflegewissenschaft. Universitat Wien : Mitteilungsblatt UG 2002 vom 27. 01. 2010, 9 Stuck, Nr 48. - Wien, 2011.-10 S.

6. Curriculum fur das Doktoratstudium Pflegewissenschaft. Universitat Wien: Mitteilungsblatt vom 23. 04. 2009, 9 Stuck, Nr 167. - Wien, 2009. - 5 S.

7. Studienplan fur das Doktoratstudium der pflegewissenschaft "Doctoral Programme Nursing Science". Medizinische Universitat Graz, 2011.-11 S. 